\title{
Reflection of Arctic geocultures in the sounding attributes of the shaman costumes of Sakha, Evenks and Nganasans
}

\author{
Oksana Dobzhanskaya*, Vera Nikiforova, Varvara Dyakonova
}

Arctic State Institute of Culture and Arts, 677000, 4 Ordzhonikidze str., Yakutsk (Sakha Republic), Russian Federation

\begin{abstract}
The purpose of this research is to study the sounding pendants on the shamanic costume of the Evenks, Sakha and Nganasans in the unity of the shamanic ritual complex and ritual musical traditions. Shamanic pendants are interpreted as a special text of culture, a reflection of the geocultural ideas of the peoples of the Arctic. The paper is based on the materials of field research carried out by the authors in Taimyr in 1989-1990, in the Olenek Evenk national region of Yakutia in 2014 and scientific publications. The sound world of shamanic ritual is a complex phonic picture, which is formed when using vocal, verbal, vocal-speech, signal, instrumental types of intonation. The movements of shaman are accompanied by the sound of colliding pendants on the costume of shamans and its components (headband, shoes, mittens). The sounding pendants were described by ethnographers and musicologists, but they were not considered in connection with geocultural studies. Metal pendants on a shaman costume mark sacred spatial models of the Universe (images of heavenly bodies - the sun, the moon, stars), mythological spaces of the Upper, Middle and Lower worlds inhabited by the shaman's helper spirits - birds, animals, anthropomorphic creatures, they symbolize parts of the human body, etc. The prospects for the study of shaman costume pendants as a symbolic embodiment of the landscape are contained in a more complete description and generalization of all known materials, including the analysis of shaman costumes from ethnographic museum collections.
\end{abstract}

\section{Introduction}

The distinctive culture of the indigenous peoples of the Arctic is one of the main factors that determine the uniqueness of the Arctic geocultures. "Arctic imagination models have unique components that contribute to the birth of "magical" and "shamanic" images of these territories" $[1,28]$.

In the interdisciplinary scientific discourse of the anthropology of cold, the imagination models of the indigenous peoples of the Arctic are considered in the cognitive dimension, which allows revealing the psycho-mental structure of the shaman's activity. A unified model of "sign-symbolic communication of a shaman with a cold landscape" was discovered on the basis of a cognitive analysis of shamanic texts among the northern Yakuts and the indigenous peoples of Taimyr. "The cultural archetypes of the ancient population of the North and the Arctic are reflected in the symbolic images of the shaman's costume as a "new body" of the shaman, revived after the initiation rite" $[2,260]$. Researchers suggest that the shamanic costume of the Yakuts "manifests the indissoluble integrity of the Perception of the Cosmos-Nature and Man" [2, 260].
The purpose of this paper is to consider the sounding pendants on the shamanic costume of the Evenks, Sakha, Nganasans in the unity of the shamanic ritual complex and ritual musical traditions. Shamanic pendants are interpreted as a special text of culture, a reflection of the geocultural ideas of the peoples of the Arctic.

\section{Materials and Methods}

The research object (pendants on the shamanic costume of the Evenks, Sakha, Nganasans) in this paper is not accidental. It is legitimate to draw parallels between these peoples on the basis of the typology of shamanism formed by them, based on common principles and demonstrating a large number of coincidences (the Central Siberian type of a drum, the type of costume, the structure of the ritual according to plot blocks, the type of responsorial singing of the shaman accompanied by assistants, phono instruments and other features) $[3,4,5]$.

An authoritative researcher of Evenk culture G. M. Vasilevich points to the influence of Evenk shamanism on neighboring peoples. In particular, he writes about the meaning of the Evenk shaman costume, which "spread not only among the peoples geographically connected with the Yenisei, but also

\footnotetext{
Corresponding author: ve.dyakonova@agiki.ru
} 
penetrated east to the Yakuts, and perhaps to other peoples of Siberia" [6, 61]. The indications of the influence of Evenk shamanism on the Nganasan (in particular, the fact that the Nganasan shamans had Evenk "teachers") is found in the works of G.N. Gracheva [7, 73].

The Evenk shaman costume is described in the works of S. M. Shirokogorov, G. M. Vasilevich, E. D. Prokofieva, I.A. Mazin and others. It is called lombolon, shamashik, samasik [8, 126; 9, 24] and was a "armor" [8, 156] or a shield [10, 67] and depicted a bird [11, 78; 12, 254], "and the skeleton on it is the spirit of the shaman himself" $[12,254]$, which also "served as a "shield" from hostile spirits during rituals" [10, 73]. "Different Tungus peoples have different shaman costumes. For example, in the Trans-Baikal region, there are three main types of costumes: a costume is a bird of the northern Barguzin and Nerchinsk Tungus, they also have a costume of red deer (for large shamans); the third one is the costume of the southern group of nomadic Tungus (cattle breeders) by its type, which is much closer to the costumes of the Buryats of the TransBaikal region" [11, 78].

According to G. M. Vasilevich: "A shaman in a costume is represented mainly as a bird and a long fringe symbolically depicts, if not wings, then feathers" [6, 61]. A. I. Mazin, on the basis of his analysis of the shaman's caftan of the Orochon Evenks, revealed that: "First of all, they reflect the idea of the helper spirits and the patron spirits; secondly, they also present the symbols of protective equipment against hostile spirits and "weapons" for fighting them; thirdly, they indicate the main types of "transport" for the "journey" of the shaman's soul and for collecting shamanic spirits. The shamanic attributes embody the idea of "voices" that help to collect spirits. Fourthly, shamanic attributes are the bodily and spiritual "receptacle" of the shaman himself and the group of Evenks he takes care of" [10, 67]. All kinds of bells, jingles, tubular pendants and plates are considered to be the receptacles of the "voices of the spirits-helpers" [10,73].

The descriptions of the earliest examples of the Yakut shaman's caftan are given in the works of political exiles, travelers and researchers of the 19th century such as I. A. Khudyakov, V. L. Seroshevsky, V. N. Vasiliev, E. K. Pekarsky, V. I. Yokhelson and others. The Yakut shaman costume, like the Evenk one, is multifunctional. "If we assume that the caftan of the Yakut shaman is similar to that of the Yukaghir, then at the moment of this transformation he becomes a bird-man. A shaman ascends to the Upper World with the help of the caftan, while he descends into the Lower World through a hole in the ice-hole disk" [13, 254].

With the help of the ritual costume, a shaman overcomes the spaces of different levels - the Upper and Lower Worlds. Like the Evenks, the iron pendants on the Yakut shaman costumes "served as a kind of armor in the fight against hostile shamans and spirits" [13, 254].
The costume of a shaman, sewn with various metal pendants, can serve as a kind of model of space: the Universe filled with various cosmic spheres - the sun, the moon, stars; a Land inhabited by birds and beasts, anthropomorphic creatures; mythological space, divided into three levels - the Upper, Middle and Lower worlds. Metal pendants of the Yakut shaman costume are described in the works of V. L. Seroshevsky, I. A. Khudyakov, V. I. Iokhelson, N. A. Alekseev. They are available in contemporary ethnographic publications.

The ethnographic data on shamanic costumes and attributes of the Nganasans are numerous. Let us mention the description of three costumes of the Nganasan shaman Duhadie, provided with drawings, made in the 1930s by A. A. Popov [14, 116-136], the works of G. N. Gracheva and E. D. Prokofieva. For the first time, musicologist I. A. Brodsky, mentioning the "small and large sets of rattles" (he and kahya, respectively) in the shaman's costume and placing on the disc "Nganasan Music" samples of their tunes performed by Demnime Kosterkin [15].

An ethnographer G. N. Gracheva conveys the statement to Tubyak Kosterkin, which helps to understand the semantics of the shaman's costume: "the main full, with all pendants, the shaman's costume is necessary as a "team". When going on a long journey, nothing can be forgotten, only then you can go far. If there is no costume, dyamada (shamanic spirits) walk only around. There are images of the main dyamadas on the costume. At the same time, the costume itself is considered the main dyamada, who knows the way in the world of $n$ go (gods) well, all the others follow his orders, he "drives the shaman's road all the time" [7, 86]. Thus, it becomes clear that the pendants on the shaman's costume are the embodiment of not only the material form, but also the supernatural essence of helper spirits.

\section{Results and Discussion}

The research process consisted of the study of the field materials collected by the authors of the paper, and the further comparison of the collected materials with information in scientific publications. Field research on the Nganasan shaman costume was carried out by the authors in Taimyr (1989) and in Novosibirsk (1990), on the Evenk costume we studied the Olenek Evenk national region of Yakutia (2014).

Let us consider the caftan of the Evenk shaman (without fringes), presented in the display of the Olenek Historical and Ethnographic Museum of the Peoples of the North. According to the information of A. P. Nikolaeva, a senior researcher at the museum, the caftan was reproduced from a reindeer suede, and the metal parts sewn onto the caftan were taken from a shaman's burial. It is known that "In 1987, $5 \mathrm{~km}$ up from the mouth of the Senke River, on the right bank of the Olenek River, a shamanic burial was excavated, which dates back to the 18th century" [16, 67]. 
The display clearly shows the back of the shaman's caftan with the following metal parts: a metal rectangle is attached to the right shoulder blade; a round disc in the middle of the back under the scapula; the figures of two birds of different types are slightly lower on the right side, the figures of three different animals are on the left; a long suede rope - a shaman's belt is attached above the waist, on two flat metal rings made of plates of different thicknesses; also a broken line elongated metal plates with pointed ends are attached on the caftan along the back along, strung in two pieces on metal brackets with rounded ends; the same details are hung under them, in the second row, but some of them are strung on circular rings.

Two long rectangular metal plates are attached to the sleeves on metal rings [17]. Shaman's belt ojuun tehiine which is $3 \mathrm{~m}$ and $52 \mathrm{~cm}$ long, made of suede, reindeer neck hair, tendon threads and wolverine wool $[18,93]$. It symbolized the reins for traveling around the worlds and during a ritual a shaman was held with the help of it.

In the given example of the Evenk shaman's caftan, the influence of Yakut shamanism is traced. The presence of a large number of metal pendants typical for Yakut shamanism indicates it. A researcher E. D. Prokofiev: "The caftans of the Vilyui Evenks had a heavy load of iron pendants, and the Yakut influence clearly affected the manner of their execution: there were long lanceolate pendants, flat bells, round plaques, solid and with holes, identical with the Yakut ones" [9, 26-27].

Field research on the Nganasan shaman costume was carried out in 1990 in Novosibirsk in cooperation between the musicologists of Novosibirsk State Glinka Conservatory (Yu. I. Sheykin, O. E. Dobzhanskaya, V.S. Nikiforova) and Estonia (T. Ojamaa). Due to the recording of the shamanic ritual of Dyulsymyaku Demnimeevich Kosterkin, the photos of his shamanic costume were taken and the comments were given on the meaning of the sounding metal pendants on his shamanic costume. This information was published in the monograph by O. E. Dobzhanskaya "Song of Hotare" [19]. In this paper, it is given as a comparative material for comparison with other cultures. The Nganasans names of the metal parts of shaman costume also are given.

The significance of the sound of the pendantsrattles in the ritual is very great, the loud ringing of the pendants symbolizes the voices of the spiritshelpers and "raises" the shaman's strength (from the comments of the shaman Dyulsimyaku Kosterkin it is clear that during the ritual he deliberately makes intense body and arm movements to make a costume - kahya-speak).

The metal images of the shaman's helper spirits are sewn to all items of a shaman's costume, without exception: kahia (shaman's costume), hialu (shaman's breastplate), yojbuka (shaman's headpiece), yodakamu (shaman's boots), yodayuhu (shaman's mittens). In addition to figurines of spirits, many metal pendants are sewn onto the costume without any specific semantics.

Figure 1 clearly shows a shaman's breastplate with a hor 'face' with eyes made of black beads and a kinto 'navel' (a circle of copper covering the shaman's navel from the blows of hostile spirits) [14, 119]. 5 semicircular badyamuo plates are sewn under the kints and up to the lower edge of the costume, one above the other. Under the lower badyamиo on metal rings are attached two pairs of colliding bells sayku 'bell'. The iron chains with bells suspended from them descend on both sides of the breastplate. Two iron plates hor are sewn on the shoulders of the costume depicting the faces of shamanic spirits.

The brass circles with a see-through ornament are below them. One copper plate кәjzəə 'rib' is sewn with through cutouts on the sides of the costume. They serve to protect the shaman's ribs from the blows of evil spirits. 2 iron plates tankazə 'humerus' are sewn to the sleeves of the shaman's costume. There are decorated with dots, which protect the shaman's hands [20]. There is an iron plate sewn in the form of an open palm diniha at the bottom of the sleeve. It protects the shaman's hand.

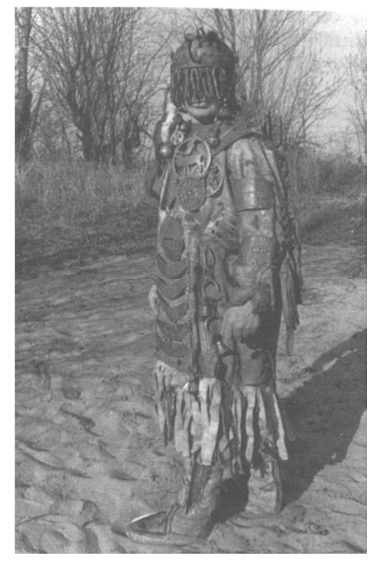

Figure 1. D. D. Kosterkin in a shaman costume (front view). Photo by A. Levkovich, 1990.

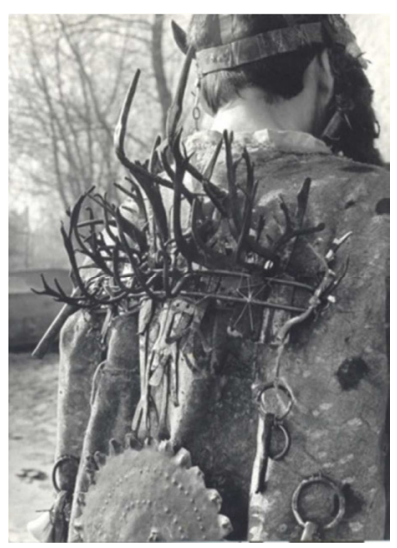

Figure 2. D.D. Kosterkin in shaman costume (back view). Photo by A. Levkovich, 1990.

Figure 2 shows the back of the shaman costume, it is hung with cone-shaped tubes connected in pairs on a ring, depicting the feathers of ornithomorphic helper 
spirits. Some bydylang tubes are suspended on the same ring with bells. On the back, between the shoulders of the shaman, iron images of spirits geese, swans, as well as deer horns are closely sewn. In the middle of the back is sewn a copper circle of the kou 'sun', in the center of which is tied a large copper bell of the sayku and a double iron chain of the mersy byny (for this chain the assistants hold the shaman during the ritual). Another copper bell is sewn to the hem of the parka in the middle.

The metal parts of the shaman's headgear yojbukəə of D.D. Kosterkin (Fig. 3) is very important. It contains helper spirits: these are metal figurines of a bear and a loon on the top of the head, an iron horn horodiata hovering like a deer on the visor, deer ears on the sides, 2 copper plates dyanta with seven projections - images of the heads of helper spirits on each. Above the right ear, an ermine skin (the shaman's helper spirit) is tied to the headgear.

Suede straps are tied on both sides to the temporal part of the headband hoop, where sounding metal pendants are attached: Dyaly-kojka the 'Idol of the Day' is a brass circle with a deer carved in the middle, a flat medallion with a rider's relief tied to it from below, copper buttons and circles with holes, small bells sayku and jingles sineri.

All the described metal pendants of the shaman costume in the broadest sense of the word represent sound instruments. During the movements of a shaman, they come into contact with other pendants and sound in some way: ringing, rattling, grinding.

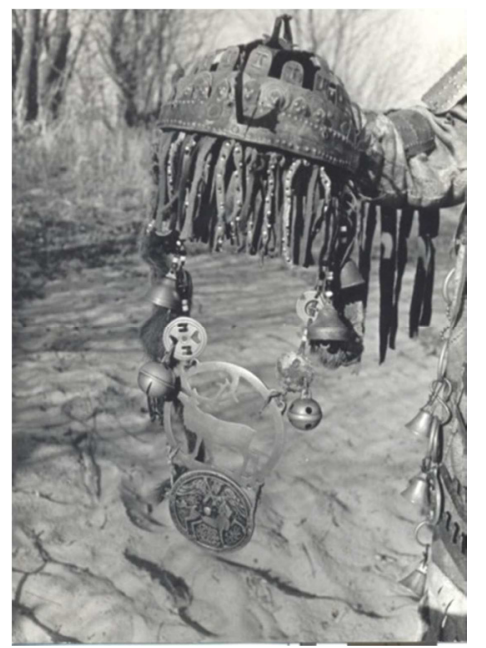

Figure 3. Shaman headgear of D. D. Kosterkin. Photo by A. Levkovich, 1990.

However, as phono instruments, it is advisable to list those of them, the sound of which during the ceremony was caused not by random reasons, but "programmed" by the structure of these rattlespendants, and which were actively involved in the creation of the sound picture of the shamanic ritual. These are: sayku - large and small bells attached to the back of the shaman's costume on chains on both sides of the breastplate, as well as on the shaman's headgear; sineri are the jingles on both sides of the shaman's cap; bydylay are cone-shaped tubes connected in pairs on the back and front of the shaman's costume; badyamuo are semicircular metal plates sewn one under the other on a metal breastplate; $l a$ are the metal rings on the shaman's costume, drum, drumstick, shaman's staff; mərsy byny is 'a rope of the shoulders', an iron chain about 2 meters long attached to the back of the costume, using which the assistants hold the shaman during the journey.

All the numerous pendants attached to the shaman's costume and giving an additional dimension to the sound picture have a general name sojbitu (nganasan. 'ringing') [21].

The data obtained during the field works on the Evenks and Nganasans must be compared with publications in scientific literature regarding the Sakha shaman costume. The caftan of the Yakut shaman has the following parts: front, back, upper, middle and lower parts. "On the front there are figures of animals, birds, fish, animals, all kinds of plaques, emblems of heavenly bodies, as well as pieces of iron depicting parts of human skeleton and entrails. According to the general belief, a piece of iron and a trinket of a shaman's dress has a soul and does not rust - ichchite" [22, 612].

"He has an iron or copper "sun" (kyun) on his chest, namely on the right side against the lower end of the sternum; besides he has the "month"(s) on the left side. Both the sun and a month are round, but only the sun is larger, their common name is Kyun kyusengete (sunbeam)" [23, 87]. "The triangles below the discs are called ojun-sulus, i.e. "Shaman stars"" [13, 257]. "Kyungeta (sun) is a round, smooth, shiny plate, the size of a tea saucer, hanging in the middle of the back, where it dangles freely on a short strap threaded through a hole made in its middle" [22, 611]. "Ojbon-kyunga (ice-hole-sun) is a plate of the same size and shape as the first one, only with a large hole in the middle; hanging on the back above the first one or hanging below on a long belt" [22, 611]. "On the back there is an image bearing the name of the sun and the split-toothed moon, a shamanic hole in the form of a ring ojbon timir, depicting a passage to the Lower World" [24, 349]. "The image of the sun, month, passage to the Lower World and clouds were used when a shaman went to the spirits of other worlds" [24, 349].

According to V. I. Yochelson metal discs are on the back of the shaman's caftan. "The top disc with a perforated hole is called ojbon-kyusenge. Ojbon is a hole through which a shaman descends into the Lower World, the world of evil spirits. The symbolic meaning of this disc is similar to the meaning of the drum in Yukaghir shamanism" [13, 253]. "Another disc with a hole is called kyun-kyusenge, i.e. a solar disk that illuminates the path of the shaman during his journey to supernatural worlds. The third disc without a hole is yj-kyusenge, i.e. lunar disk" [13, 253].

"On the humerus bones of both hands there are two birdie ije chyokchyongyotyo (mother of waders). On the right shoulder there is an iron depiction of a 
Siberian Crane (ije kytalyga is a mother of Siberian Cranes) three inches long with eyes, head, neck and leg. On the left shoulder there is a loon (kuogas). During the service, these birds are smeared, i.e. they are fed with mare's blood" [23, 87]. "The number of birds ranges from three to seven. Images were sewn in different places: on the back, on the breastplate and under the sleeve" [24, 349].

"Over the iron in front, on each side of the chest, there is half a man with eyes and a quarter-sized head, made of red copper. This image is called the "mother of emigetei" (devils) (ije emigete)" [23, 88]. "Emeget, emeget abaasyta is a copper plate as long as the index finger, and half the width of the palm. It depicts a person: "with legs, arms, head, nose, mouth, eyes and ears", or an openwork copper medallion with a human figure in the middle" [22, 612]. Kyuler-emeget, that is laughing emeget, the other is d'es emeget, i.e. copper emeget.

Vasiliev and Pekarsky believe that the copper emeget is an image of the head of a yuyor, i.e. a wandering soul of a dead man who has become an evil spirit iirer emeget, i.e. rampaging (going crazy) emeget. This is an image of one of the spirits of the Upper World, which causes madness" [13, 257]. "Some shamans do not have a loon on their dress, but on the lower back there is an iron image of a wolf or a bear" [23, 87].

The Yakut shaman's cloak also contains special sounding details called kyasaan (iron pendants on shaman's clothes [25, col. 1356]). The ringing made by the ritual vestments of the "elder" protects him from evil spirits when traveling to other worlds.
There are the following types of kyasaan: kyongdyoj kyasaan are "iron or "tin" tubes that are empty inside, as thick as the ring finger, but longer than it; they are usually set on the back, on rings or metal hinges" [25, 1356]; chyllyryt kyasaan are "flat plates as long as a small finger and approximately with the same width; hang in a set above the waist on the back" [22, 611]. According to the explanation of Sleptsov (Yakut from the Megino-Kangalassky ulus of the Yakutsk district), they represent the "feathers of birds", the shaman's helper spirits [13, 252].

Let's continue the description of the types of kyasaan: hobo kyasaan are iron rattles in the form of folding shells on the back of the shaman's costume in the uppermost part on the left [25, 1356]; hongho kyasaan is a conical tube on a shaman's costume [25, 1356]; kyrbas kyasaan are iron pendants (in pieces) on shaman's clothes [25, 1356]; d'yl kyasaan is a tail in the form of an iron arrow with iron pendants on the sides [13, 258].

These phono instruments, according to their names and descriptions, differ mainly in shapes and sizes. For example, d'yl kyasaan resembles an arrow, chyllyryt kyasaan and kyrbas kyasaan are made of metal plates (pieces of metal), and kyongdyoj kyasaan, hongho kyashaan and hobo kyasaan are metal tubular rattles. It is necessary to note that the name of the cone-shaped tube hongho kyasaan is similar to the name of bells hongho or hongh among the Mongols, Kalmyks, Buryats and Tuvinians [26, 645].

\section{Conclusion}

Table 1. Geocultural symbols in shaman costume pendants

\begin{tabular}{|c|c|c|c|c|c|}
\hline \multirow{3}{*}{ People } & \multicolumn{5}{|c|}{ Geocultural symbols } \\
\hline & \multicolumn{2}{|c|}{ Space-time symbols } & \multirow{2}{*}{ Zoomorphic symbols } & \multirow{2}{*}{ Anthropomorphic symbols } & \multirow{2}{*}{$\begin{array}{c}\begin{array}{c}\text { Ornithomorphic } \\
\text { symbols }\end{array} \\
\end{array}$} \\
\hline & Myphological & Cosmic & & & \\
\hline Sakha & $\begin{array}{l}\text { Upper world; } \\
\text { Middle world; } \\
\text { Lower world }\end{array}$ & $\begin{array}{l}\text { kyun-sun; yj } \\
\text { - month; kyun } \\
\text { kyusengete- } \\
\text { sunray; ojun- } \\
\text { sulus - } \\
\text { shaman stars; } \\
\text { clouds }\end{array}$ & $\begin{array}{l}\text { ije chyokchyongyotyo- } \\
\text { mother of sandpipers; ije } \\
\text { kytalyga-mother of } \\
\text { Siberian Cranes; kuogas } \\
\text { - loon; gull; wolf; bear; } \\
\text { balyk-timir - fish }\end{array}$ & $\begin{array}{l}\text { ije emegete - mother of } \\
\text { emeget (devils); kyuler-emeget } \\
\text { - laughing emeget; d'es } \\
\text { emeget - copper emeget head } \\
\text { of yuyor - a wandering soul of } \\
\text { a dead man who became an } \\
\text { evil spirit; iirer emeget - } \\
\text { rampaging (going crazy) } \\
\text { emeget }\end{array}$ & $\begin{array}{l}\text { Plate rattles chyllyryt } \\
\text { kyasaan - "Bird } \\
\text { feathers", shaman's } \\
\text { helper spirits }\end{array}$ \\
\hline Evenks & $\begin{array}{l}\text { Upper world; } \\
\text { Middle world; } \\
\text { Lower world }\end{array}$ & $\begin{array}{l}\text { - Universe; } \\
\text { - sun; } \\
\text { - month; }\end{array}$ & $\begin{array}{l}\text { Insects; butterflies; agdy } \\
\text { bird; ukeng - loon; } \\
\text { woodpecker; hawk; two- } \\
\text { headed bird; eared bird; } \\
\text { mammoth; Tiger; bear; } \\
\text { Wolf; frog; snake; lizard; } \\
\text { taimen }\end{array}$ & Spirits amaku & $\begin{array}{l}\text { The metal plates on the } \\
\text { sleeves depicted bones } \\
\text { and wing joints }\end{array}$ \\
\hline Nganasans & $\begin{array}{l}\text { Upper world; } \\
\text { Lower world } \\
\text { Basa are iron } \\
\text { pendants (iron as a } \\
\text { material seems to } \\
\text { be associated with } \\
\text { the world of } \\
\text { spirits) }\end{array}$ & $\begin{array}{l}\text { Kou-Sun } \\
\text { Kicheze- } \\
\text { Moon } \\
\text { Dyaly-kojka- } \\
\text { the idol of the } \\
\text { day } \\
\text { Badyamuo - } \\
\text { crescent- } \\
\text { shaped metal } \\
\text { breastplate }\end{array}$ & $\begin{array}{l}\text { Harka-bear } \\
\text { Harka-nemy - female } \\
\text { bear } \\
\text { Syr selu - White stag- } \\
\text { choir, leader of the herd } \\
\text { (name of the shamanic } \\
\text { spirit) } \\
\text { Tamuyku - lemming } \\
\text { Hezy - ermine } \\
\text { Hotarye Byza Tangu- } \\
\text { the Water God-Deer } \\
\text { Koti-nemy - The mother } \\
\text { of cows }\end{array}$ & $\begin{array}{l}\text { Hora - face, disguise (sewn on } \\
\text { the chest of a shaman's caftan } \\
\text { on both sides of the head) } \\
\text { Dyanta - the plates with } \\
\text { semicircular protrusions - the } \\
\text { images of the heads of the } \\
\text { spirits-helpers }\end{array}$ & $\begin{array}{l}\text { Metallic images of } \\
\text { spirits-helpers (debtu } \\
\text { geese, dyaykujkya } \\
\text { swans) on the back of a } \\
\text { shaman's costume. } \\
\text { Hotare - loon (spirit- } \\
\text { helper). } \\
\text { Bydylay (tubes) - } \\
\text { symbolize feathers of } \\
\text { ornithomorphic helper } \\
\text { spirits. }\end{array}$ \\
\hline
\end{tabular}


Table 2. Sounding pendants of the shaman costume as a phonoinstrument

\begin{tabular}{|c|c|c|c|}
\hline \multirow{2}{*}{ № } & \multirow{2}{*}{ People } & \multirow{2}{*}{ Sound tools } & Hornbostel-Sachs classification \\
\hline & & & Idiophones \\
\hline 1. & \multirow[t]{6}{*}{ Sakha } & hobo kyasaan - falling icicles bells strung on a string & 111.14 colliding vessels or vaso-clappers \\
\hline 2. & & kyrbas kyasaan from metal plates & $\begin{array}{l}\text { 112.112.1 shaking strung rod rattles in the } \\
\text { form of plates (the index supplemented by } \\
\text { V.D.) }\end{array}$ \\
\hline 3. & & kyongdyoj kyasaan - hollow iron bells on shaman costume & $\begin{array}{l}\text { 112.112.2 shaking strung rod-shaped rattles } \\
\text { in the form of tubes (the index is } \\
\text { supplemented by V.D.) }\end{array}$ \\
\hline 4. & & hongho kyasaan - conical tube & $\begin{array}{l}\text { 112.112.2 shaking strung rod-shaped rattles } \\
\text { in the form of tubes (the index is } \\
\text { supplemented by V.D.) }\end{array}$ \\
\hline 5. & & keltegej hobo - round rattle on the back of the shaman costume & 112.121 shaking rattle \\
\hline 6. & & hobo chuoraan - bells on shaman costume & 112.13 shaking rattle \\
\hline 7. & \multirow[t]{6}{*}{ Evenks } & hollow cone-shaped elongated metal pendant & 111.14 colliding vessels or vaso-clappers \\
\hline 8. & & tubular pendants & The same \\
\hline 9. & & bells & $\begin{array}{l}111.242 .122 \text { beatable single hanging tongue } \\
\text { bells }\end{array}$ \\
\hline 10. & & $\begin{array}{l}\text { metal "knife-pendant" in the form of a flat elongated diamond-shaped } \\
\text { plate }\end{array}$ & $\begin{array}{l}\text { 112.112.1 shaking strung rod rattles in the } \\
\text { form of plates (the index supplemented by } \\
\text { V.D.) }\end{array}$ \\
\hline 11. & & metal rims & $\begin{array}{l}112.112 .3 \text { shaking strung bar rattles in the } \\
\text { form of rims (the index supplemented by } \\
\text { V.D.) }\end{array}$ \\
\hline 12. & & jingles & 112.13 shaking rattles \\
\hline 13. & \multirow[t]{10}{*}{ Nganasans } & $\begin{array}{l}\text { Bydylay - conical tubes connected in pairs on the back and front of the } \\
\text { shaman costume }\end{array}$ & 112.11 shaking idiophones (stringed rattles) \\
\hline 14. & & $\begin{array}{l}\text { Badyamиo - semicircular metal plates sewn one under the other on the } \\
\text { shaman's breastplate }\end{array}$ & The same \\
\hline 15. & & Sayku - big and small bells & The same but in the form of bell \\
\hline 16. & & Sigeri - jingles & 112.13 shaking rattles \\
\hline 17. & & $L a-$ metal rings on the shaman costume, tambourine, mallet, shaman staff & 112.11 shaking idiophones (stringed rattles) \\
\hline 18. & & Metal buttons & The same \\
\hline 19. & & $\begin{array}{l}\text { Mersy byny ("shoulder rope") - an iron chain about } 2 \text { meters long attached } \\
\text { to the back of the costume, using which assistants hold the shaman during } \\
\text { the journey }\end{array}$ & The same \\
\hline 20. & & $\begin{array}{l}\text { Kahya - shaman's caftan with metal pendants (I. Brodsky: a large set of } \\
\text { rattles) }\end{array}$ & $\begin{array}{l}112.11 \text { shaking idiophones (set of stringed } \\
\text { rattles) }\end{array}$ \\
\hline 21. & & $H e-$ small set of rattles (I. Brodsky) & $\begin{array}{l}112.11 \text { shaking idiophones (set of stringed } \\
\text { rattles) }\end{array}$ \\
\hline 22. & & $\begin{array}{l}\text { Sojbitu "Sounding master" - all the numerous pendants attached to the } \\
\text { shaman's costume and giving additional dimension to the sound picture } \\
\text { (Field materials, information from D.D. Kosterkin) }\end{array}$ & $\begin{array}{l}112.11 \text { shaking idiophones (set of stringed } \\
\text { rattles) }\end{array}$ \\
\hline
\end{tabular}

The results of the study of sounding pendants on shamanistic costumes of Sakha, Evenks and Nganasans are presented in Tables 1 and 2. Table 1 clearly shows the classification of sounding pendants of a shaman's costume as a symbolic code of the Universe (cosmic and mythological symbols, images of zoo- and anthropomorphic creatures, due to the special importance of the image of birds ornithomorphic symbols are shown in a separate column). Table 2, analyzes the pendants of the shaman's costume as sound instruments according to the organological systematics of E. von Hornbostel and K. Sachs [27, 238-241]. National terms of sound instruments and their descriptions are given.

A. I. Mazin found out that in the pendants of the Evenk shaman costume: "the idea of the universe, with its main planets, upper and lower worlds, is reflected" [10, 67]. We see that this idea is confirmed by the materials described in the article (kyun - the sun; yj - month; kyun kyusengete - a sunbeam; ojun-sulus - shaman stars on the Yakut shaman costume; sun kou, the idol of the day Dyalykojka on the Nganasan shaman costume and etc.).
The images of zoomorphic helper spirits (bear, deer, birds - geese, loons, swans and others) are not just symbols of spiritual beings, they also embody the realistic features of animals and birds, and therefore reflect the richness of the animal world of the tundra and taiga. A part of an animal may be depicted (for example, the colliding tubes bydylang on the Nganasan shamanic costume symbolically embody bird feathers).

Some metal pendants of the shaman's costume, symbolizing the helper spirits, have an anthropomorphic appearance (the ornamental motifs of the "singing" heads on the shoulder ornaments and the headpiece of the Nganasan shaman's costume). Many metal pendants do not have a realistic resemblance to objects of nature or space and their main purpose is to create a ritual phonic effect during shamanic rituals. The topic of the sound of metal pendants on a shaman's costume as sacred phono instruments is not fully studied. It significantly expands the interdisciplinary discourse of anthropological research in the Arctic. In particular, the concept of the sounding landscape of the Arctic can be expanded and it can get new semantic facets including information about the 
sounding pendants of the shaman's costume. The authors do not claim to be complete in the study of this issue, since a limited number of materials were included in the review. The prospects for the study of the pendants of shaman costume as a symbolic embodiment of the landscape are contained in a more complete description and generalization of all known materials, including the analysis of shaman costumes from ethnographic museum collections.

Moreover, it is possible to expand the list of compared peoples on the basis of ethnocultural unity, both within linguistic groups (northern Türks, northern Tungus-Manchus, Samoyed peoples) and in musical and ethnographic regions (Central Siberian, North-Western, North-Eastern)

\section{References}

1. D. N. Zamyatin, Geocultural space of the Arctic: ontological models of imagination, Geocultures of the Arctic: methodology of analysis and applied research. 28-37 (2017)

2. E. N. Romanova, O. E. Dobzhanskaya, Anthropology of cold: methodology, concepts, images (on the example of cultural traditions of the indigenous peoples of the North and the Arctic), Bulletin of the Tomsk State University: Cultural Studies and Art History, 35, P. 255-263 (2019)

3. Yu. I. Sheykin, Musical culture of the peoples of North Asia (Ministry of Culture of the Republic of Sakha (Yakutia), Yakutsk, 1996)

4. Yu. I. Sheykin, The history of the musical culture of the peoples of Siberia: Comparative-historical research (Vostochnaya literature, Moscow, 2002)

5. E. S. Novik, Rite and Folklore in Siberian Shamanism: An Experience of Comparing Structures (Nauka, Moscow, 1984)

6. G. M. Vasilevich, Tunguska bib among the peoples of Siberia, Collection of the Museum of Anthropology and Ethnography, XI, 4261 (1949)

7. G. N. Gracheva, Shamans among the Nganasans, Problems of the history of social consciousness of the aborigines of Siberia, 69-89 (1981)

8. G. M. Vasilevich. Ancient hunting and reindeer breeding rituals of the Evenks, Collection of the Museum of Anthropology and Ethnography, XVII, 151-185 (1957)

9. E. D. Prokofiev, Shamanic costumes of the peoples of Siberia, Religious ideas and rituals of the peoples of Siberia in the 19th - early 20th centuries, Collection of the Museum of Anthropology and Ethnography, 27, 5-100 (1971)
10. A. I. Mazin, Traditional beliefs and rituals of the Orochon Evenks (late 19th - early 20th centuries) (Nauka, Novosibirsk, 1984)

11. S. M. Shirokogorov, Experience in researching the foundations of shamanism among the Tungus, Scientific notes of the Faculty of History and Philology in Vladivostok, I, 47-108 (1919)

12. G. M. Vasilevich, Evenks. Historical and ethnographic essays (18th - early 20th century) (Nauka, Leningrad, 1969)

13. V. I. Yokhelson, Yukaghirs and Yukaghized Tunguses (Nauka, Novosibirsk, 2005)

14. A. A. Popov, Nganasans: Social structure and beliefs (Nauka, Novosibirsk, 1984)

15. I. A. Brodsky, Nganasan music, annotation to the vinyl record (1982)

16. S. I. Boyakova (ed.), Oleneksky ulus: history, culture, folklore (Bichik, Yakutsk, 2005)

17. V. Ye. Dyakonova Field data. Materials of a musical and ethnographic expedition to the Oleneksky Evenk national region of Yakutia (2014)

18. E. S. Shishigin (ed.), Circumpolar civilization in the museums of the world: yesterday, today, tomorrow. Museums of the Republic of Sakha (Yakutia). Catalogue (CIP NBR Sakha, Yakutsk, 2009)

19. O. E. Dobzhanskaya, Song of Hotare. Shamanic rite of the Nganasans: an experience of ethnomusicological research (DROFA, Saint Petersburg, 2002)

20. O. E. Dobzhanskaya Field materials of comments by Dyulsimyaku Kosterkin to his shaman costume (1990)

21. O. E. Dobzhanskaya. Field data from The village of Ust-Avam, Taimyr Autonomous Okrug (1989)

22. V. L. Seroshevsky, Yakuts: Experience of Historical Research (The Association "The Russian Political Encyclopedia", Moscow, 1993)

23. I. A. Khudyakov, Brief description of the Verkhoyansk District: (Selected chapters) (Bichik, Yakutsk, 2002)

24. N. A. Alekseev (ed.), Yakuts (Sakha) (Nauka, Moscow, 2012)

25. E. K. Pekarsky, Dictionary of the Yakut language, 2 (Moscow, 1959)

26. M. V. Esipova (ed.), Musical instruments. Encyclopedia (Deka-VS, Moscow, 2008)

27. E. Hornbostel, K. Sachs, Systematics of musical instruments, Folk musical instruments and instrumental music. Collection of articles and materials in two parts, 1, 229-261 (1987) 